\title{
Türkiye'de Makroekonomik Faktörler ile Sağlık Harcamaları ve Sağlık Bakanlığı Bütçesi Arasındaki İlişkinin ARDL Sınır Testi Yaklaşımı ile İncelenmesi
}

\section{Investigation of the Relationship between Macroeconomic Factors and Health Expenditures and Ministry of Health Budget in Turkey through ARDL Bounds Testing Approach}

\author{
Ümit ÇRAKLI ${ }^{1}$
}

\section{$\ddot{O} z$}

Bu çalışmanın amacı, Türkiye'de makroekonomik faktörler ile sağlık harcamaları ve Sağlık Bakanlığı bütçesi arasındaki ilişkilerin ve makroekonomik faktörlerdeki değişimin bu değişkenleri etkileyip etkilemediğinin ortaya konulmasıdır. Bu kapsamda, 1974-2015 yılları arası reel GSYH, işsizlik, enflasyon, sağlık harcamaları ve Sağlık Bakanlığı bütçesi verileri ARDL (Autoregressive Distributed Lag) sınır testi yaklaşımı kullanılarak incelenmiştir. Çalışma sonucunda, gelir artışının Türkiye'de sağlığa ayrılan kaynakları artırdığı, Türkiye'de kamu sağlık harcamalarında genel olarak genişletici politikanın tercih edildiği ve Türkiye'de özellikle son on yılda sosyal güvenlik sisteminin güçlendirilmesi ile makroekonomik değişimlerin olası olumsuz sağlık etkilerinin önlenmesi kapasitesinin arttığı sonucuna ulaşılmıştır.

Anahtar Kelimeler: Sağlık harcamaları, bütçe, makroekonomik faktörler, ARDL sınır testi

Makale Türü: Araştırma

\begin{abstract}
The aim of this study is to reveal the relationship between macroeconomic factors and health expenditures and Ministry of Health budget, whether the changes in macroeconomic factors affect these variables in Turkey. In this context, real GDP, unemployment, inflation and health expenditures between 1974 and 2015 were examined using the ARROL (Autoregressive Distributed Lag) bounds testing approach. As a result of the study, it is concluded that the increase in income increases the resources allocated to health in Turkey, that expansionary policies are generally preferred in public health expenditures in Turkey and, that the capacity to prevent possible negative health effects of macroeconomic changes has increased with the strengthening of the social security system, especially in the last decade, in Turkey.
\end{abstract}

Keywords: Health expenditures, budget, macroeconomic factors, ARDL bound testing

Paper Type: Research

\section{Giriş}

Sağlık ve hastalığın tanımları, dönemin özelliklerine, tanımlandığı kültüre, sağlığa bakıŞ açılarına ve toplumdaki güçlü grupların ideolojisine göre değişebilmektedir (Şahin, 1996; Somunoğlu, 2012). Sağlıkla ilgili tanımların sağlığı genel olarak negatif ve pozitif açıdan tanımladığ1 görülmektedir (Aggleton, 1990).

Negatif açıdan sağlık, hastalık (disease) ya da rahatsızlık (illness) durumunun olmayış1 olarak tanımlanmaktadır. Hastalık, vücudun herhangi bir yerinde bir dizi belirti ya da işaretlerle

\footnotetext{
${ }^{1}$ Yozgat Bozok Üniversitesi, İktisadi ve İdari Bilimler Fakültesi, umit.cirakli@bozok.edu.tr, Orcid ID: https://orcid.org/0000-00023134-8830.

Atıf için (to cite): Çıraklı, Ü. (2019). Türkiye'de Makroekonomik Faktörler ile Sağlık Harcamaları ve Sağlık Bakanlığı Bütçesi Arasındaki İlişkinin ARDL Sınır Testi Yaklaşımı ile İncelenmesi. Afyon Kocatepe Üniversitesi Sosyal Bilimler Dergisi, 21(2), 581596.
} 
kendini gösteren, bazı patolojik bulguların veya anormalliklerin bulunması olarak ifade edilmektedir. Rahatsızlık ise ağrı, sıkıntı ve endişe gibi hastalıkla birlikte bulunabilen ya da bulunmayan hisleri ifade etmektedir (Aggleton, 1990).

Pozitif açından ise sağlık daha geniş bir yaklaşımla belirli niteliklerin bulunması olarak tanımlanmaktadır (Aggleton, 1990). Pozitif sağlık tanımları içinde Dünya Sağlık Örgütü’nün 1948 yılında yaptığı sağlık tanımı ön plana çıkmaktadır. Buna göre "sağlık, sadece hastalık veya sakatlığın olmayışı değil, fiziksel sosyal ve ruhsal yönden tam bir iyilik halidir” (WHO, 1948). $\mathrm{Bu}$ tanıma göre sağlık çok boyutlu bir kavramdır ve birbiriyle ilişkili birçok faktör sağlığ etkilemektedir (Kavuncubaşı ve Yıldırım, 2010). Bu faktörler sağlı̆̆ın belirleyicileri olarak ele alınmaktadır.

Sağlığın belirleyicileri ile ilgili modellerin hemen hepsinde (Blum, 1974; Lalonde, 1974, Evans ve Stoddart, 1990; Dahlgren ve Whitehead, 1991; Brunner ve Marmot, 2005) ekonominin sağlığın önemli bir belirleyicisi olduğu görülmektedir. $\mathrm{Bu}$ nedenle, ekonomik koşullarda meydana gelecek değişimlerin de, yönünden bağımsız olarak (negatif veya pozitif) sağlığa etkilerinin olacağını belirtmek mümkündür. Örneğin ekonomik krizlerde gelir düştüğü için, insan sağlığı gelir düşüşünden olumsuz etkilenebilmektedir (Kontorovich, 2001; Tangcharoensathien vd., 2000).

\section{Teorik Çerçeve}

Ekonomik faktörlerdeki iyileşmelerin genel olarak sağlık üzerinde olumlu etkileri olmaktadır. Hanehalkı gelirlerinin artması sağlık hizmeti ihtiyaçlarının finansmanını kolaylaştırmaktadır. Yine aile üyelerindeki işsizliğin azalması, istihdama dayalı sağlık sigortasının kaybını engellemekte ve sağlı hizmeti ihtiyaçlarının karşılanmasına imkân sağlamaktadır (HPC - Healthy Public Policy, 2009). Ekonomik şartlardaki iyileşmeler hanehalklarını sağlık açısından olumlu etkilerken kamu kaynaklarının da artması sonucu sağlık sistemleri için de olumlu bir ortam yaratmaktadır (Thomas vd., 2013). Bilindiği gibi sağlık harcamaları ile GSYH arasında aynı yönlü bir ilişki vardır. Genellikle GSYH arttığında sağlık harcamaları da artmaktadır. Bu ilişki açısından bakıldığında, ekonomik kriz zamanlarında GSYH'nin düşüşü ile doğru orantılı olarak sağlık harcamalarının da düşeceğini söylemek mümkündür (Keegan vd., 2013). Çünkü kriz dönemleri, sağlık hizmetlerinin de içinde yer aldığ1 birçok alanda harcamalarda kesintilere neden olmaktadır (Catalano, 2009; Ruckert ve Labonte, 2012; Thomas vd., 2013). Sağlı hizmetlerinde yapılacak bu kesintiler, sağlık hizmeti kalitesini ve bulunabilirliğini etkilemektedir (Christian, 2009; Tangcharoensathien vd., 2000).

Darby ve Melitz (2008) sağlı harcamalarının kriz dönemlerinde artabileceğine dair teorik bazı nedenler öne sürmektedir. İlk olarak kriz döneminde zamanın firsat maliyetinin düşük olması, sağlık hizmetlerine daha fazla odaklanmaya neden olabilir. Krizler, önemli onarımlar ve mevcut sermeyenin yenilenmesi için firsat sağlamaktadır. Ayrıca kriz döneminde devlet destekli sağlık programları için gerekli şartları taşıyan insan sayısı da artabilir (Darby ve Melitz, 2008). Yukarıdaki görüşün aksine Del Grenado ve diğerleri (2010) kamu sağlık harcamalarının gelişmekte olan ülkelerde krizle aynı yönde (pro-cyclical), gelişmiş ülkelerde ise krizden bağımsız değişim gösterdiğini savunmaktadır.

\section{Gereç ve Yöntem}

\subsection{Araştırmanın Amacı}

$\mathrm{Bu}$ çalışmanın amacı, makroekonomik faktörler ile sağlık harcamaları ve Sağlık Bakanlığı bütçesi arasındaki ilişkilerin ve makroekonomik faktörlerdeki değişimin sağlık harcamalarını ve Sağlık Bakanlığg bütçesini etkileyip etkilemediğinin ortaya konulmasıdır.

\subsection{Araștırmanın Veri Seti}

Çalı̧̧manın verileri, 1974-2015 yılları arası toplam 42 gözlem olmak üzere yıllık olarak elde edilmiştir. Çalışmada kamu, özel ve toplam sağlık harcamaları ile Sağlık Bakanlığı 
bütçesine bağımlı değişkenler olarak yer verilmiştir. Reel GSYH, işsizlik ve enflasyon oranları ise makroekonomik göstergeler ve bağımsız değişkenler olarak kullanılmıştır. Bu verilere ek olarak, 1994, 2001 ve 2009 ekonomik krizleri ise kukla değişkenler olarak modellere dahil edilmiştir. Bu değişkenlerin kodlanması ise, reel GSYH'nin negatif olduğu yıllara 1, diğerlerine ise 0 verilerek gerçekleştirilmiştir.

Tablo 1. Veriler, kısaltmaları ve veri kaynağı

\begin{tabular}{lcc}
\hline \multicolumn{1}{c}{ Veriler } & Kısaltmaları & Veri Kaynağı \\
\hline $\begin{array}{l}\text { Kamu Sağlık Harcamalarının Toplam Sağlık } \\
\text { Harcamaları İçindeki \%'si }\end{array}$ & KSHTSHY & OECD, 2016 \\
\hline $\begin{array}{l}\text { Özel Sağlık Harcamalarının Toplam Sağlık } \\
\text { Harcamaları İçindeki \%'si }\end{array}$ & OZSHTSHY & OECD, 2016 \\
\hline $\begin{array}{l}\text { Toplam Sağlık Harcamalarının GSYH } \\
\text { İçindeki \%'si }\end{array}$ & TSHGDP & OECD, 2016 \\
\hline $\begin{array}{l}\text { Sağlık Bakanlığı Bütçesinin Genel Bütçe } \\
\text { İçindeki Payı (\%) }\end{array}$ & SBGDP & BUMKO, 2016 \\
\hline Reel GSYH & RGSYH & World Bank (2016a) \\
\hline $\begin{array}{l}\text { İşizlik oranı } \\
\text { Enflasyon oranı }\end{array}$ & ISSIZ & $\begin{array}{c}\text { TÜIK (2016), Kalkınma Bakanlığı } \\
\text { (2015), Bulutay (1995) }\end{array}$ \\
\hline
\end{tabular}

\subsection{Yöntem ve Verilerin Analizi}

Bu çalışmada, makroekonomik faktörler ile sağlık harcamaları ve Sağlık Bakanlığı bütçesi arasındaki ilişkiyi ortaya koymak için zaman serileri analizi kapsamında ARDL sınır testi yaklaşımı kullanılmıştır. Zaman serileriyle değişkenler arasındaki uzun dönemli ilişkilerin tespiti için geliştirilen eşbütünleşme analizlerinin temelinde, serilerin durağanlık dereceleri yatmaktadır. Bu bağlamda tüm değişkenler düzey değerlerinde durağan yani $\mathrm{I}(0)$ iseler, model sıradan en küçük kareler (OLS) tekniğiyle tahmin edilebilir (Çiftci ve Yıldız, 2015). Pesaran vd. (2001) tarafından geliştirilen ARDL sınır testi yaklaşımı, açıklayıcı değişkenlerin tümünün I(1) olmasını gerektirmemektedir. Bundan dolayı ARDL yaklaşımında değişkenlerin birim kök taşıyıp taşımadıklarını test etmek bir zorunluluk değildir (Pesaran vd., 2001; Bahmani-Oskooee ve $\mathrm{Ng}, 2002$ ). Diğer taraftan, modeldeki bağımlı değişkenin I (1) olması ve ayrıca analizde kullanılması planlanan değişkenlerden hiç birinin I(2) olmaması gerekliliği bulunmaktadır. Çünkü Pesaran, Shin ve Smith (2001) tarafından verilen alt ve üst kritik değerler, serilerin I(0) ve I(1) olma durumlarına göre elde edilmiştir. Dolayısıyla, en azından bu bahsedilen şartların sağlanıp sağlanmadığından emin olmak için, ARDL yaklaşımı kullanılmadan önce birim kök testleri yapılarak, serilerin durağanlık derecelerinin tespit edilmesi yararlı olacaktır (Çiftci, 2009).

ARDL eşbütünleşme yönteminin gerçekleştirilmesinde, EViews 9.5 istatistik programı kullanılmıştır. ARDL yöntemi dört aşamada gerçekleştirilmiştir. İlk olarak, zaman serileri için birim kök testi uygulanmıştır. Birim kök testi içinse yaygın olarak kullanılan Augmented Dickey-Fuller (ADF) - Genişletilmiş Dickey-Fuller testi kullanılmıştır (Tunçsiper ve Biçen, 2013; Çiftci, 2009). İkinci aşamada bir Kısıtsız Hata Düzeltme Modeli (UECM) kurulmuş ve model OLS (En küçük kareler) tekniği ile tahmin edilerek sınır testi (wald testi) yapılmıştır. Wald testi sonucunda elde edilen F istatistiği değeri Pesaran vd. (2001) tarafından türetilen alt ve üst kritik değerler ile karşılaştırılarak değişkenler arasında eşbütünleşme ilişkisi olup olmadığına karar verilmiştir. UECM'de yer alan her bir değişken için optimal gecikme uzunluğu hesaplanmasında ise Akaike bilgi kullanılmıştır. Tahmin edilen model için belirlenecek maksimum gecikme uzunluğunun belirlenmesinde ise otokorelasyon probleminin bulunmadığı gecikme uzunluğu dikkate alınmıştır. Otokorelasyon problemi bulunup bulunmadığı ise Breusch-Godfrey otokorelasyon LM testi ile tespit edilmiştir. Ayrıca seçilen modelin tanısal testleri kapsamında, normal dağılıma uygunluk için Jarque-Bera testi, değişen varyans için $\mathrm{ARCH}$ testi, model kurma yâda başka bir deyişle fonksiyonel biçim hatası için 
Ramsey Reset testi gerçekleştirilmiştir. Ayrıca modelin kararlı̆̆ını tespit için CUSUM ve CUSUM-SQ testleri yapılmıştır. Üçüncü aşamada ise, uzun dönem katsayılarını belirlemek için ARDL modeli tahmin edilmiştir. Bu aşamada maksimum gecikme uzunluğunun tespitinde Akaike bilgi kriteri kullanılmıştır. Tahmin edilen model için, yine tanısal testler gerçekleştirilmiştir. Dördüncü aşamada ise ARDL modelinden yararlanılarak Hata Düzeltme Modeli (ECM) oluşturulmuş ve bu model OLS tekniği yardımıyla tahmin edilmiştir.

\section{Bulgular ve Tartışma}

\subsection{Birim Kök Testi Sonuçları}

Analizde kullanılan zaman serilerinin durağanlıklarının belirlenmesinde ADF birim kök testi kullanılmıştır. Tablo 2'de ilgili zaman serilerine ait ADF birim kök testi sonuçları gösterilmektedir. Tabloda yer alan ADF birim kök testi sonuçlarına göre, kamu sağlık harcamalarının toplam sağlı harcamaları içindeki payı serisinin yalnızca sabitsiz ve trendsiz (hiçbiri) modelde düzey değerlerinde durağan olmayıp birinci fark değerlerinde durağan olma koşulunu sağladığı anlaşılmaktadır. Bu nedenle, kamu sağlık harcamalarının analizinde sabitsiz ve trendsiz model kullanılmıştır. Diğer bağımlı değişkenlerin ise, üç model türü için de düzey değerlerinde durağan olmayıp birinci fark değerlerinde durağan olma koşulunu sağladıkları görülmektedir. Ancak Sağlık Bakanlığı bütçesi ile ilgili yapılan analizlerde, sabit ve trendli model haricindekilerde, sınır testini geçemedikleri veya tanısal istatistiklerle ilgili ihlallerin fazla olması nedeniyle sabit ve trendli model ile analiz gerçekleştirilmiştir.

Tablo 2. Birim kök testi sonuçları

\begin{tabular}{|c|c|c|c|c|c|}
\hline \multirow{2}{*}{ Değişkenler } & \multirow{2}{*}{ Modeller } & \multicolumn{2}{|c|}{ Düzey Değerleri } & \multicolumn{2}{|c|}{ Birinci Fark Değerleri } \\
\hline & & $\mathbf{t}$ & $\mathbf{p}$ & $\mathbf{t}$ & $\mathbf{p}$ \\
\hline \multirow{3}{*}{ LRGSYH } & Sabit & $-0,39$ & 0,901 & $-6,44 * * *$ & 0,000 \\
\hline & Sabit ve Trend & $-3,20$ & 0,098 & $-6,35 * * *$ & 0,000 \\
\hline & Hiçbiri & 6,21 & 1,000 & $-2,66 * * *$ & 0,009 \\
\hline \multirow{3}{*}{ LENF } & Sabit & $-0,88$ & 0,781 & $-6,26 * * *$ & 0,000 \\
\hline & Sabit ve Trend & $-2,05$ & 0,554 & $-6,53 * * *$ & 0,000 \\
\hline & Hiçbiri & $-0,53$ & 0,480 & $-6,32 * * *$ & 0,000 \\
\hline \multirow{3}{*}{ LISSIZ } & Sabit & $-2,14$ & 0,227 & $-5,50$ *** & 0,000 \\
\hline & Sabit ve Trend & $-2,40$ & 0,372 & $-5,43 * * *$ & 0,000 \\
\hline & Hiçbiri & 0,40 & 0,795 & $-5,54 * * *$ & 0,000 \\
\hline \multirow{3}{*}{ LKSHTSHY } & Sabit & $-1,617$ & 0,463 & $-1,849$ & 0,3513 \\
\hline & Sabit ve Trend & $-1,420$ & 0,838 & $-1,982$ & 0,5905 \\
\hline & Hiçbiri & 1,092 & 0,925 & $-1,679 *$ & 0,0876 \\
\hline \multirow{3}{*}{ LOZSHTSHY } & Sabit & $-0,82$ & 0,800 & $-5,26 * * *$ & 0,000 \\
\hline & Sabit ve Trend & $-2,49$ & 0,328 & $-5,18 * * *$ & 0,000 \\
\hline & Hiçbiri & $-1,47$ & 0,130 & $-5,89 * * *$ & 0,000 \\
\hline \multirow[t]{3}{*}{ LTSHGDP } & Sabit & $-0,82$ & 0,801 & $-6,82 * * *$ & 0,000 \\
\hline & Sabit ve Trend & $-1,98$ & 0,593 & $-6,74 * * *$ & 0,000 \\
\hline & Hiçbiri & 1,02 & 0,917 & $-6,62 * * *$ & 0,000 \\
\hline \multirow[t]{3}{*}{ LSBBGDP } & Sabit & $-2,34$ & 0,164 & $-7,27 * *$ & 0,000 \\
\hline & Sabit ve Trend & $-2,70$ & 0,238 & $-7,22 * * *$ & 0,000 \\
\hline & Hiçbiri & $-0,39$ & 0,535 & $-7,36 * * *$ & 0,000 \\
\hline
\end{tabular}

Not: *\%10 anlamlılık düzeyini, **\%5 anlamlılık düzeyini, ***\%1 anlamlılık düzeyini ifade etmektedir.

\subsection{Kısıtsız Hata Düzeltme Modeli (UECM) Tahmin Sonuçları}

Kamu sağlık harcamalarının toplam sağlık harcamaları içindeki payı, özel sağlık harcamalarının toplam sağlık harcamaları içindeki payı, toplam sağlık harcamalarının GSYH içindeki payı, Sağlık Bakanlığı bütçesinin genel bütçe içindeki payı enflasyon oranı, reel GSYH 
ve işsizlik değişkenlerine ilişkin oluşturulan ve kukla değişkenleri de içeren UECM modellerinin tahmin sonuçları Tablo 3 'te yer almaktadır.

Tablo 3'teki bilgilere göre, LKSHTSHY (kamu sağlık harcamaları) için elde edilen F testi değerinin (4,31) Pesaran, Shin ve Smith (2001) tarafından Tablo CI(i)'de verilen üst sınır kritik değerlerin üzerinde olduğu (\%2,5 anlamlılık düzeyinde); LOZSHTSHY (özel sağlık harcamaları) için elde edilen F testi değerinin $(6,01)$ Tablo CI(ii)'de verilen üst sınır kritik değerlerin üzerinde olduğu; LTSHGDP (toplam sağlık harcamaları) için elde edilen F testi değerinin $(6,01)$ Tablo CI(ii)'de \%5 anlamlılık düzeyi için verilen üst sınır kritik değerlerin üzerinde olduğu ve LSBBGBP (Sağlık Bakanlığı bütçesi) için elde edilen F testi değerinin $(4,29)$ Tablo CI(iv)'de \%5 anlamlılık düzeyi için verilen üst sınır kritik değerlerin üzerinde olduğu anlaşılmaktadır. Modellerin tanısal istatistikleri açısından da (otokorelasyon sorunu, hata teriminin normal dağılıma uygun olduğu, değişen varyans sorunu ve model kurma hatası) bir probleminin olmadığ 1 görülmektedir. Ayrıca, tahmin edilen ARDL modellerinin istikrarlı olup olmadığına dair CUSUM ve CUSUM-SQ grafiklerine göre, modellere ait katsayıların istikrarlı olduğu anlaşılmaktadır.

Tablo 3. ARDL sınır testi tahmin sonuçları

\begin{tabular}{|c|c|c|c|c|c|c|}
\hline Bağımlı Değişken & $\begin{array}{c}\text { Tahmin Edilen ARDL } \\
\text { Modeli }\end{array}$ & $\mathbf{k}$ & $\mathbf{F}$ & $\mathbf{p}$ & $\mathbf{R} 2$ & D-R2 \\
\hline LKSHTSHY & {$[2,4,4,2]$} & 3 & 4,31 & 0,016 & 0,85 & 0,65 \\
\hline Tanısal Testler* & \multicolumn{6}{|c|}{$\begin{array}{l}\text { SE: 0,157; SSE: 0,372; S.C.: 1,16, p: 0,377; J.-B.Nor.: 0,55, p: 0,755; Het.: } \\
\text { 0,19, p: 0,659; F.Res: 0,03, p: 0,859 }\end{array}$} \\
\hline Bağımlı Değişken & $\begin{array}{c}\text { Tahmin Edilen ARDL } \\
\text { Modeli }\end{array}$ & $\mathbf{k}$ & $\mathbf{F}$ & $\mathbf{p}$ & $\mathbf{R 2}$ & D-R2 \\
\hline LOZSHTSHY & {$[2,2,2,0]$} & 3 & 6,01 & 0,001 & 0,73 & 0,53 \\
\hline Tanısal Testler* & \multicolumn{6}{|c|}{$\begin{array}{l}\text { SE: 0,180; SSE: 0,719; S.C.: 1,14, p: 0,338; J.-B.Nor.: 3,29, p: 0,192; Het.: } \\
\text { 0,05, p: 0,808; F.Res: 0,62, p: 0,438 }\end{array}$} \\
\hline Bağımlı Değişken & $\begin{array}{c}\text { Tahmin Edilen ARDL } \\
\text { Modeli }\end{array}$ & $\mathbf{k}$ & $\mathbf{F}$ & $\mathbf{p}$ & $\mathbf{R 2}$ & D-R2 \\
\hline LTSHGDP & {$[2,4,4,4]$} & 3 & 4,10 & 0,020 & 0,82 & 0,47 \\
\hline Tanısal Testler* & \multicolumn{6}{|c|}{$\begin{array}{l}\text { SE: 0,073; SSE: 0,064; S.C.: 2,47, p: 0,128; J.-B.Nor.: 2,21, p: 0,329; Het.: } \\
\text { 0,48, p: 0,489; F.Res: 2,11, p: 0,174 }\end{array}$} \\
\hline Bağımlı Değişken & $\begin{array}{l}\text { Tahmin Edilen ARDL } \\
\text { Modeli } \\
\end{array}$ & $\mathbf{k}$ & $\mathbf{F}$ & $\mathbf{p}$ & $\mathbf{R 2}$ & D-R2 \\
\hline LSBBGBP & {$[2,4,0,0]$} & 3 & 4,29 & 0,008 & 0,62 & 0,28 \\
\hline Tanısal Testler* & \multicolumn{6}{|c|}{$\begin{array}{l}\text { SE: 0,150; SSE: 0,432; S.C.: 1,94, p: 0,155; J.-B.Nor.: 0,26, p: 0,877; Het.: } \\
\text { 2,24, p: 0,143; F.Res: 1,14, p: 0,375 }\end{array}$} \\
\hline
\end{tabular}

Tablo CI (i): \%1: alt limit 3,42 - üst limit 4,84; \% 2,5: alt limit 2,87 - üst limit 4,16; \%5: alt limit 2,45 - üst limit 3,63; \% 10: alt limit 2,01 - üst limit 3,10.

Tablo CI (ii): \% 1: alt limit 3,65 - üst limit 4,66; \% 2,5: alt limit 3,15 and üst limit 4,08; \%5: alt limit 2,79 and üst limit 3,67; \%10: alt limit 2,37 and üst limit 3,20 .

Tablo CI (iv): \% 1: alt limit 4,30 - üst limit 5,23; \% 2,5: alt limit 3,80 - üst limit 4,68; \%5: alt limit 3,38 - üst limit 4,23; \% 10: alt limit 2,97 - üst limit 3,74.

* Tanısal Testler Bölümündeki Kısaltmaların Anlamları; SE: Standart Hata, SSE: Standart Hatalar Toplamı, S.C.: Breusch-Godfrey LM otokorelasyon testi, J.-B.Nor.: Jarque-Bera normallik testi, Het.: ARCH testi, F.Res.: Ramsey Reset testi 


\subsection{ARDL Modeli Uzun ve Kısa Dönem Katsayıları Tahmin Sonuçları}

\subsubsection{Kamu Sağlık Harcamalarının Toplam Sağlık Harcamaları İçindeki Payı}

$\mathrm{Bu}$ aşamada genel bir ARDL modeli, maksimum gecikme uzunluğu 4 alınarak ve en uygun gecikme uzunluğu seçiminde Akaike bilgi kriteri kullanılarak OLS tekniği ile tahmin edilmiştir. Tahmin sonuçlarına göre, ARDL $[1,4,3,3]$ modelinin en uygun model olduğuna karar verilmiştir*. ARDL modeli ve uzun dönem katsayılarının tahmininden sonra son olarak kısa dönem katsayılarının tahmin edilmesi amacıyla hata düzeltme modeli oluşturulmuş ve yine en küçük kareler tekniği ile model tahmin edilmiştir.

Tablo 4. ARDL modeli uzun ve kısa dönem tahmin sonuçları: kamu sağlık harcamalarının toplam sağlık harcamaları içindeki payı

\begin{tabular}{|c|c|c|c|c|c|c|c|}
\hline \multicolumn{8}{|c|}{ Tahmin Edilen ARDL Modeli: $[1,4,3,3]$} \\
\hline \multicolumn{4}{|c|}{$\begin{array}{l}\text { Uzun Dönem Modeli } \\
\text { Bağımlı Değișken: LKSHTSHY }\end{array}$} & \multicolumn{4}{|c|}{$\begin{array}{c}\text { Kısa Dönem Modeli (ECM) } \\
\text { Bağımlı Değişken: } \Delta \text { LKSHTSHY }\end{array}$} \\
\hline Değişkenler & Katsayı & $\mathbf{t}$ & $\mathbf{p}$ & Değişkenler & Katsayı & $\mathbf{t}$ & p \\
\hline \multirow{4}{*}{ LENF } & \multirow{4}{*}{$-0,331$} & \multirow{4}{*}{$-0,838$} & \multirow{4}{*}{0,411} & $\triangle \mathrm{LENF}$ & 0,482 & $4,868 * * *$ & 0,000 \\
\hline & & & & $\Delta \operatorname{LENF}(-1)$ & $-0,121$ & $-1,306$ & 0,206 \\
\hline & & & & $\triangle \mathrm{LENF}(-2)$ & $-0,045$ & $-0,523$ & 0,606 \\
\hline & & & & $\triangle \mathrm{LENF}(-3)$ & $-0,367$ & $-4,197 * * *$ & 0,000 \\
\hline \multirow{3}{*}{ LRGSYH } & \multirow{3}{*}{0,753} & \multirow{3}{*}{$2,099 * *$} & \multirow{3}{*}{0,048} & $\triangle \mathrm{LRGSYH}$ & 1,767 & 1,639 & 0,116 \\
\hline & & & & $\Delta$ LRGSYH(-1) & $-1,982$ & $-1,851$ & 0,078 \\
\hline & & & & $\Delta$ LRGSYH(-2) & $-1,778$ & $-2,292 * *$ & 0,032 \\
\hline \multirow{3}{*}{ LISSIZ } & \multirow{3}{*}{$-5,899$} & \multirow{3}{*}{$-1,676$} & \multirow{3}{*}{0,109} & $\Delta$ LISSIZ & 0,855 & $2,169 * *$ & 0,042 \\
\hline & & & & $\Delta \operatorname{LISSIZ(-1)}$ & $-0,891$ & $-2,133 * *$ & 0,045 \\
\hline & & & & $\Delta \operatorname{LISSIZ(-2)}$ & 1,293 & $3,666 * * *$ & 0,001 \\
\hline D_1994 & 1,190 & 0,797 & 0,435 & $\Delta \mathrm{D} \_1994$ & 0,144 & 0,827 & 0,418 \\
\hline D_2001 & $-4,072$ & $-1,336$ & 0,196 & $\Delta \mathrm{D} \_2001$ & $-0,667$ & $-3,020 * * *$ & 0,007 \\
\hline \multirow[t]{2}{*}{ D_2009 } & 2,502 & 1,306 & 0,206 & $\Delta \mathrm{D} \_2009$ & 0,389 & $2,331 * *$ & 0,030 \\
\hline & & & & $\operatorname{ECM}(-1)$ & $-0,150$ & $-3,587 * * *$ & 0,002 \\
\hline \multicolumn{8}{|c|}{$\begin{array}{c}\mathbf{E C M}=\text { LKSHTSHY - (-0,3309*LENF + 0,7530*LRGSYH -5,8993*LISSIZ +1,1901*D_1994 - } \\
\text { 4,0718*D_2001 + 2,5017*D_2009) }\end{array}$} \\
\hline \multicolumn{8}{|c|}{$\begin{array}{l}\text { Tanısal Testler: SE: 0,180; SSE: 0,683; S.C.: 1,423, p: 0,269; J.-B.Nor.: 0,320, p: 0,848; Het.: 0,295, p: } \\
\text { 0,591; F.Res: 5,061, p: 0,035 }\end{array}$} \\
\hline
\end{tabular}

* Tanısal Testler Bölümündeki Kısaltmaların Anlamları; SE: Standart Hata, SSE: Standart Hatalar Toplamı, S.C.: Breusch-Godfrey LM otokorelasyon testi, J.-B.Nor.: Jarque-Bera normallik testi, Het.: ARCH testi, F.Res.: Ramsey Reset testi

Tablo 4'te ARDL [1, 4, 3, 3] modelinin uzun ve kısa dönem katsayılarının tahmin sonuçları ve tanısal istatistikleri yer almaktadır. Tablo 4 'te yer alan bilgilere göre tahmin edilen ARDL [1, 4, 3, 3] modelinin tanısal istatistikler açısından (otokorelasyon, normal dağılıma uygunluk, değişen varyans ve model kurma hatası) herhangi bir probleminin bulunmadığ anlaşılmaktadır. Ayrıca uzun dönem katsayılarının istikrarlı olup olmadığını göstermek üzere Şekil 1'de yer alan CUSUM ve CUSUM-SQ test sonuçlarının grafiksel gösterimine göre, CUSUM-SQ grafiğinde küçük bir taşma olmakla birlikte tekrar kritik sınırlar içinde döndüğü için ARDL sınır testi sonucunda elde edilen uzun dönem katsayılarının katsayıların istikrarlı olduğunu ifade etmek mümkündür.

\footnotetext{
${ }^{*}$ En uygun ARLD modelinin seçimi, seçilen bilgi kriteri ve maksimum gecikme uzunluğuna göre Eviews 9.5 paket programı tarafindan otomatik olarak yapılmaktadır.
} 
Şekil 1. ARDL CUSUM ve CUSUM-SQ grafikleri: kamu sağlık harcamalarının toplam sağl1k harcamaları içindeki payı
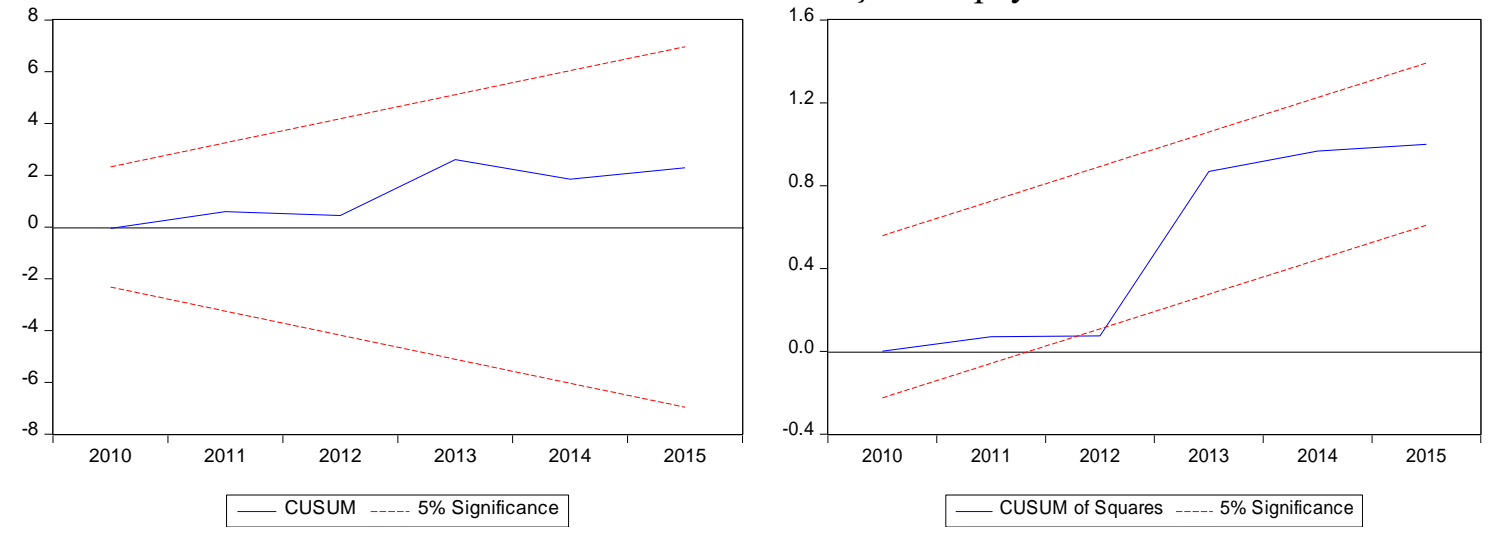

Tablo 4'te yer alan sonuçlara göre ECM(-1)'in katsayısının negatif $(-0,15)$ ve istatistiksel olarak anlamlı olduğu görülmektedir. Hata düzeltme modelinin katsayısından ($0,15)$ kısa dönemli şokların sistem uzun dönem dengesinde neden olacağı sapmaların \%15'nin bir dönem sonrasında giderileceğini ve sistemin yaklaşık olarak 6 dönemden kısa bir zaman sonra tekrar uzun dönem dengesine döneceğini söylemek mümkündür.

Tablo 4'te yer alan uzun dönem katsayılarından, enflasyon oranı ve işsizlik oranı ile kamu sağlık harcamalarının toplam sağlık harcamaları içindeki payı arasında ters yönlü bir ilişki bulunmakla birlikte, bu ilişkilerin istatistiksel olarak anlamlı olmadığ $1(\mathrm{p}>0,05)$ tespit edilmiştir. $\mathrm{Bu}$ sonuçlardan, enflasyon ve işsizliğin ile kamu sağlık harcamalarının toplam sağlık harcamaları içindeki payını uzun dönemde anlamlı bir şekilde etkilemediği anlaşılmaktadır. Reel GSYH ile kamu sağlık harcamalarının toplam sağlık harcamaları içindeki payı arasında ise uzun dönemde doğru yönlü $(0,753)$ ve istatistiksel olarak anlamlı $(\mathrm{p}=0,048)$ bir ilişki bulunduğu tespit edilmiştir. Bu sonuçtan, reel GSYH'de meydana gelen artışın kamu sağlık harcamalarının toplam sağlık harcamaları içindeki payını artırdığını söylemek mümkündür. Uzun dönemde reel gelir arttığında kamu sağlık harcamalarının toplam sağlık harcamaları içindeki payının artması beklenebilir bir durumdur. Çünkü gelir artışı kamunun sağlığa yeterli kaynak ayırabilmesinin önemli bir unsurudur.

Tablo 4'te yer alan kısa dönem katsayılarından, 1994 ekonomik krizinin pozitif yönlü olmakla birlikte kamu sağlık harcamalarının toplam sağlık harcamaları içindeki payı üzerinde istatistiksel olarak anlamlı bir etkide bulunmadığ $1(\mathrm{p}=0,418)$ tespit edilmiştir. 2001 ekonomik krizi kamu sağlık harcamalarının toplam sağlık harcamaları içindeki payı üzerinde anlamlı bir şekilde $(\mathrm{p}=0,007)$ negatif yönlü $(-0,667)$ etkide bulunurken, 2009 ekonomik krizinin ise pozitif yönlü $(0,389)$ ve istatistiksel olarak anlamlı bir etki yaptığı $(\mathrm{p}=0,030)$ tespit edilmiştir. $\mathrm{Bu}$ sonuçlardan, 1994 ekonomik krizinin kamu sağlık harcamalarının toplam sağlık harcamaları içindeki payı üzerinde anlamlı bir etki yapmadığı, 2001 krizinin azaltıcı ve 2009 krizinin ise artırıcı bir etkide bulunduğu söylenilebilir.

Bu çalışmanın Sağlık Bakanlığı bütçesiyle ilgili bölümünde (Tablo 7), 2001 ekonomik krizinde bütçede görülen anlamlı artış düşünülürse, 2001 ekonomik krizinin insanların sağlık hizmetlerini ertelemeleri yönünde bir etkide bulunarak kamu sağlık harcamalarının toplam sağlık harcamaları içindeki payının önemli şekilde azalmasına neden olmuş olabileceği düşünülmektedir. 2009 ekonomik krizinden sonra artışın ise doğrudan politik tercihle ilgili olduğu söylenilebilir. Çünkü kamu sağlık harcamalarının kriz dönemlerinde artmasında veya azalmasında uygulanacak politikalar önemli bir rol oynamaktadır. 


\subsection{2 Özel Sağlık Harcamalarının Toplam Sağlık Harcamaları İçindeki Payı}

Özel sağlık harcamalarının toplam sağlık harcamaları içindeki payı modeli için uzun ve kısa dönem katsayıları, Eviews 9.5 paket programı ile genel bir ARDL modeli, maksimum gecikme uzunluğu 2 alınarak ve en uygun gecikme uzunluğu seçiminde Akaike bilgi kriteri kullanılarak OLS tekniği ile tahmin edilmiştir. Tahmin sonuçlarına göre, ARDL [2, 2, 0, 2] modelinin en uygun model olduğuna karar verilmiştir. Daha sonra, kısa dönem katsayılarının tahmin edilmesi amaciyla hata düzeltme modeli oluşturulmuş ve yine en küçük kareler tekniği ile model tahmin edilmiştir. Tablo 5’te ARDL [2, 2, 0,2] modelinin uzun ve kısa dönem tahmin sonuçları ve tanısal istatistikleri yer almaktadır.

Tablo 2. ARDL modeli uzun ve kısa dönem tahmin sonuçları: özel sağlık harcamalarının toplam sağlı harcamaları içindeki payı

\begin{tabular}{|c|c|c|c|c|c|c|c|}
\hline \multicolumn{8}{|c|}{ Tahmin Edilen ARDL Modeli: $[2,2,0,2]$} \\
\hline \multicolumn{4}{|c|}{$\begin{array}{c}\text { Uzun Dönem Modeli } \\
\text { Bağımlı Değişken: LOZSHTSHY } \\
\end{array}$} & \multicolumn{4}{|c|}{$\begin{array}{c}\text { Kısa Dönem Modeli (ECM) } \\
\text { Bağımlı Değişken: } \Delta \text { LOZSHTSY }\end{array}$} \\
\hline Değișkenler & Katsayı & $\mathbf{t}$ & $\mathbf{p}$ & Değişkenler & Katsayı & $\mathbf{t}$ & p \\
\hline \multirow{2}{*}{ LENF } & \multirow{2}{*}{$-0,170$} & \multirow{2}{*}{0,060} & \multirow{2}{*}{0,009} & $\triangle \mathrm{LENF}$ & $-0,168$ & $-3,404$ & 0,002 \\
\hline & & & & $\triangle \operatorname{LENF}(-1)$ & $-0,060$ & $-1,294$ & 0,207 \\
\hline \multirow{2}{*}{ LRGSYH } & \multirow{2}{*}{$-1,105$} & \multirow{2}{*}{0,072} & \multirow{2}{*}{0,000} & $\triangle \mathrm{LRGSYH}$ & $-1,971$ & $-3,963$ & 0,001 \\
\hline & & & & $\triangle \mathrm{LRGSYH}(-1)$ & $-0,694$ & $-1,410$ & 0,170 \\
\hline LISSIZ & $-0,051$ & 0,290 & 0,862 & $\Delta$ LISSIZ & 0,064 & 0,384 & 0,704 \\
\hline D_1994 & $-0,328$ & 0,183 & 0,085 & $\Delta \mathrm{D} \_1994$ & $-0,156$ & $-1,925$ & 0,065 \\
\hline D_2001 & $-0,267$ & 0,204 & 0,201 & $\Delta \mathrm{D} \_20($ & $-0,135$ & $-1,678$ & 0,105 \\
\hline D_2009 & $-0,848$ & 0,281 & 0,006 & $\Delta \mathrm{D} \_2009$ & $-0,555$ & $-5,628$ & 0,000 \\
\hline Sabit & 31,933 & 2,113 & 0,000 & $\operatorname{ECM}(-1)$ & $-0,618$ & $-4,756$ & 0,000 \\
\hline \multicolumn{8}{|c|}{$\begin{array}{c}\text { ECM= LOZSTSHY }-(-0,1702 * \text { LENF }-1,1048 * \text { LRGSYH }-0,0508 * \text { LISSIZ }-0,3276 * \text { D_1994 - } \\
\left.0,2673 * \mathrm{D} \_2001 \quad-0,8481 * \mathrm{D} \_2009+31,9326\right)\end{array}$} \\
\hline \multicolumn{8}{|c|}{$\begin{array}{c}\text { Tanısal Testler: SE: 0,096; SSE: 0,248; S.C.: 0,256, p: 0,617; J.-B.Nor.: 0,740, p: 0,687; Het.: 0,784, p } \\
\text { 0,382; F.Res: 0,800, p: 0,379 }\end{array}$} \\
\hline
\end{tabular}

* Tanısal Testler Bölümündeki Kısaltmaların Anlamları; SE: Standart Hata, SSE: Standart Hatalar Toplamı, S.C.: Breusch-Godfrey LM otokorelasyon testi, J.-B.Nor.: Jarque-Bera normallik testi, Het.: ARCH testi, F.Res.: Ramsey Reset testi

Tablo 5'te yer alan bilgilere göre, tahmin edilen ARDL [2, 2, 0, 2] modelinin tanisal istatistikler açısından (otokorelasyon, normal dağılıma uygunluk, değişen varyans ve model kurma hatası) herhangi bir probleminin bulunmadığı anlaşılmaktadır. Ayrıca Şekil 2'de yer alan, uzun dönem katsayılarının istikrarlı olup olmadığını göstermek üzere CUSUM ve CUSUM-SQ test sonuçlarına göre, modele ait uzun dönem katsayılarının istikrarlı olduğu anlaşılmaktadır.

Tablo 5'te yer alan sonuçlardan hata düzeltme modelinin katsayısına göre $(-0,61$ ve p: $\mathrm{p}=0,000)$. Bu sonuçtan, sistemin uzun dönem dengesinde kısa dönemli şoklar nedeniyle oluşacak sapmaların hızlı bir şekilde giderileceğini ve iki dönem sonra ermeden sistemin uzun dönem dengesine geleceğini söylemek mümkündür. 
Şekil 2: ARDL CUSUM ve CUSUM-SQ grafikleri: özel sağlık harcamalarının toplam sağlık harcamaları içindeki payı
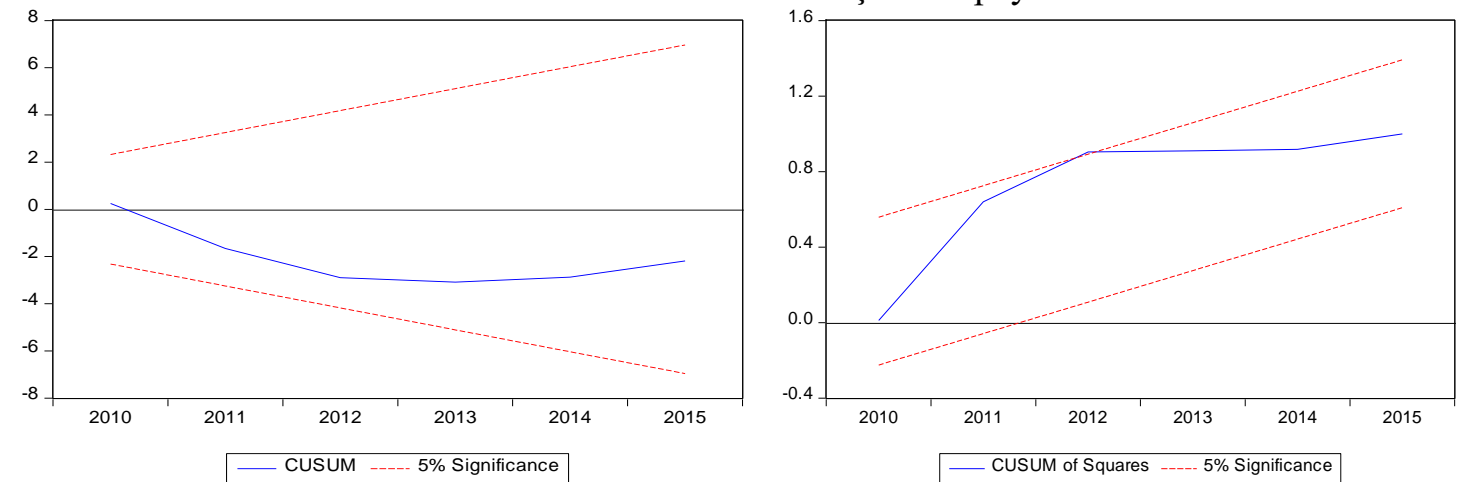

Tablo 5'te yer alan uzun dönem katsayılarından, enflasyon oranının uzun dönem katsayısının ters yönlü $(-0,170)$ ve istatistiksel olarak anlamlı $(\mathrm{p}=0.009)$ olduğu görülmektedir. $\mathrm{Bu}$ sonuçtan, uzun dönemde enflasyon oranındaki artışın özel sağlık harcamalarının toplam sağlık harcamaları içindeki payını azalttığını söylemek mümkündür. Enflasyon artışı, diğer mal ve hizmetlerin fiyatlar genel düzeyinde bir artışın yanında aynı zamanda önemli ölçüde tıbbi cihaz ve malzeme ithalatçısı konumundaki Türkiye (İTO - İstanbul Ticaret Odası ve Sargutan, 2009; Kalkınma Bakanlığı, 2014) için sağlık hizmetlerinin maliyetlerinin artması anlamına gelmektedir. Bu durumun, bireylerin özel sağlık harcamalarını azaltmasına önemli bir etken olduğu düşünülmektedir. Çünkü tıbbi mal ve hizmetlerin fiyatının artması bireylerin özel sağlık harcaması yapma imkanını önemli ölçüde kısıtlayacaktır.

Tablo 5'teki bilgilere göre, uzun dönemde, reel GSYH meydana gelen artı̧̧ özel sağlik harcamalarının toplam sağlık harcamaları içindeki payını anlamlı bir şekilde azaltıcı etki yapmaktadır. Bu sonuçtaki önemli bir unsurun, Türkiye'nin sahip olduğu sosyal güvence sistemi olduğu düşünülmektedir. Türkiye'de sağlık hizmetleri sunumu genel olarak kamu ağırlıklı geçekleştirilmekte ve finansmanı ağırlıklı olarak sosyal sigorta modeline (Bismarck modeli) dayanmaktadır (Özer, Yıldırım ve Yıldırım, 2015; Yıldırım ve Yıldırım, 2015). Son on yılda bu sistem daha da güçlendirilmiş ve GSS (Genel Sağlık Sigortası) ile tüm nüfus kapsama alınmıştır. Bu kapsamda sosyal güvence sisteminin ve kapsamının güçlü olması bireylerin özel sağlık hizmetlerine daha az ihtiyaç duymalarına ve dolayısıyla daha az özel sağlık harcaması yapmalarına neden olmuş olabilir.

Tablo 5'te işsizlik ile özel sağlık harcamalarının toplam sağlık harcamaları içindeki payı arasındaki uzun dönemli ilişkiye bakıldığında, ters yönlü bir ilişki bulunmakla birlikte bu ilişkinin istatistiksel olarak anlamlı olmadığ $1(p>0,05)$ tespit edilmiştir.

Tablo 5'teki kısa dönem katsayılarına ilişkin bilgilere göre, 1994, 2001 ve 2009 ekonomik krizlerinin özel sağlık harcamalarının toplam sağlık harcamaları içindeki payı üzerinde ters yönlü etkide bulundukları görülmektedir. Ancak bu etkilerden sadece 2009 ekonomik krizinin etkisinin $(-0,555)$ istatistiksel olarak anlamlı olduğu $(p=0,000)$ tespit edilmiştir. Özel sağlık harcamalarının toplam sağlık harcamaları içindeki payının düşmesinde, kriz nedeniyle özel sektöre olan talebin düşmesi ve aynı zamanda kamu sağlık programlarına için elverişli kişi sayısının artmasının etkili olabileceği değerlendirilmektedir.

\subsubsection{Toplam Sağlık Harcamalarının GSYH İçindeki Payı}

Eviews 9.5 paket programı ile Toplam sağlık harcamalarının GSYH içindeki payına ilişkin genel bir ARDL modeli ile, maksimum gecikme uzunluğu 5 alınarak ve en uygun gecikme uzunluğu seçiminde Akaike bilgi kriteri kullanılarak modelin uzun ve kısa dönem katsayıları OLS tekniği ile tahmin edilmiştir. Tahmin sonuçlarına göre, ARDL $[2,5,5,5]$ modelinin en uygun model olduğuna karar verilmiştir. Daha sonra kısa dönem katsayılarının tahmin edilmesi amaciyla hata düzeltme modeli oluşturulmuş ve yine en küçük kareler tekniği 
ile model tahmin edilmiştir. Tablo 6'da ARDL $[2,5,5,5]$ modelinin uzun ve kısa dönem katsayılarının tahmin sonuçları ve tanısal istatistikleri yer almaktadır.

Tablo 6'daki verilerden, tahmin edilen ARDL $[2,5,5,5]$ modelinin tanisal istatistikler açısından normal dağılıma uygunluk dışında (otokorelasyon, değişen varyans ve model kurma hatası) herhangi bir probleminin bulunmadığı anlaşılmaktadır. Williams, Grajales ve Kurkiewicz (2013)'in belirttiği gibi çoklu regresyonda diğer varsayımlar karşılandığı sürece hata teriminin normal dağılım göstermemesi regresyon katsayılarının yanılgılı ve tutarsız olduğu anlamına gelmemektedir. Yine yazarlara göre örneklem büyüklüğ̈̈ arttıkça, hataların dağılım normal olmasa bile katsayılarla ilgili çıkarımlar daha güvenilir hale gelecektir. Bu kapsamda, diğer tanısal istatistiklerde problem olmadığı için modelin tahmin açısından sorunlu olmadığı söylenilebilir.

Tablo 6: ARDL modeli uzun ve kısa dönem tahmin sonuçları: toplam sağlık harcamalarının GSYH içindeki pay1

\begin{tabular}{|c|c|c|c|c|c|c|c|}
\hline \multicolumn{8}{|c|}{ Tahmin Edilen ARDL Modeli: $[2,5,5,5]$} \\
\hline \multicolumn{4}{|c|}{$\begin{array}{l}\text { Uzun Dönem Modeli } \\
\text { Bağımlı Değișken: LTSHGDP }\end{array}$} & \multicolumn{4}{|c|}{$\begin{array}{c}\text { Kısa Dönem Modeli (ECM) } \\
\text { Bağımlı Değișken: } \Delta \text { LTSHGDP }\end{array}$} \\
\hline Değişkenler & Katsayı & $\mathbf{t}$ & $\mathbf{p}$ & Değişkenler & Katsayı & $t$ & $\mathbf{p}$ \\
\hline \multirow{5}{*}{ LENF } & \multirow{5}{*}{$-0,043$} & \multirow{5}{*}{$-0,180$} & \multirow{5}{*}{0,860} & $\Delta \mathrm{LENF}$ & $-0,137$ & $-3,872 * * *$ & 0,002 \\
\hline & & & & $\Delta \operatorname{LENF}(-1)$ & $-0,015$ & $-0,452$ & 0,659 \\
\hline & & & & $\Delta \operatorname{LENF}(-2)$ & $-0,078$ & $-2,266 * *$ & 0,041 \\
\hline & & & & $\Delta \operatorname{LENF}(-3)$ & $-0,017$ & $-0,523$ & 0,610 \\
\hline & & & & $\mathrm{NF}(-4)$ & $0,1^{7}$ & $5,872 * * *$ & 0,000 \\
\hline \multirow{5}{*}{ LRGSYH } & \multirow{5}{*}{1,366} & \multirow{5}{*}{2,057} & \multirow{5}{*}{0,060} & $\Delta$ LRGSYH & $-0,988$ & $-2,581 * *$ & 0,023 \\
\hline & & & & $\Delta$ LRGSYH(-1) & $-0,599$ & $-1,424$ & 0,178 \\
\hline & & & & $\Delta$ LRGSYH(-2) & $-0,308$ & $-0,977$ & 0,346 \\
\hline & & & & $\triangle$ LRGSYH(-3) & 0,955 & $2,983 * *$ & 0,011 \\
\hline & & & & $\Delta$ LRGSYH(-4) & 1,376 & $4,545 * * *$ & 0,001 \\
\hline \multirow{5}{*}{ LISSIZ } & \multirow{5}{*}{$-2,239$} & \multirow{5}{*}{$-0,817$} & \multirow{5}{*}{0,428} & $\Delta$ LISSIZ & 0,254 & 1,787 & 0,097 \\
\hline & & & & $\Delta \operatorname{LISSIZ(-1)}$ & 0,346 & 1,652 & 0,123 \\
\hline & & & & $\Delta \operatorname{LISSIZ(-2)}$ & 0,179 & 1,145 & 0,273 \\
\hline & & & & $\Delta$ LISSIZ(-3) & 0,428 & $3,466 * * *$ & 0,004 \\
\hline & & & & $\Delta \operatorname{LISSIZ(-4)}$ & 0,567 & $4,263 * * *$ & 0,001 \\
\hline D_1994 & $-0,567$ & $-0,903$ & 0,383 & $\Delta \mathrm{D} \_1994$ & $-0,039$ & $-0,626$ & 0,542 \\
\hline D_2001 & $-1,345$ & $-1,119$ & 0,284 & $\Delta \mathrm{D} \_2001$ & $-0,276$ & $-3,965 * * *$ & 0,002 \\
\hline D_2009 & $-1,004$ & $-1,245$ & 0,235 & $\Delta$ D_2009 & $-0,272$ & $-4,402 * * *$ & 0,001 \\
\hline Sabit & $-27,639$ & $-2,213 * *$ & 0,045 & $\mathrm{ECM}(-1)$ & $-0,238$ & $-6,979 * * *$ & 0,000 \\
\hline \multicolumn{8}{|c|}{$\begin{array}{c}\text { ECM= LTSHGDP }-(-0,0433 * \text { LENF + 1,3658*LRGSYH }-2,2389 * \text { LISSIZ }-0,5667 * \text { D_1994 - } \\
1,3447 * \text { D_2001 }-1,0038 * \text { D_2009 }-27,6393\end{array}$} \\
\hline \multicolumn{8}{|c|}{$\begin{array}{c}\text { Tanısal Testler: SE: 0,071; SSE: 0,065; S.C.: 3,088, p: 0,076; J.-B.Nor.: 2,91, p: 0,232; Het.: 2,33, } \\
\text { p: 0,136; F.Res: 27,56, p: 0,000 }\end{array}$} \\
\hline
\end{tabular}

* Tanısal Testler Bölümündeki Kısaltmaların Anlamları; SE: Standart Hata, SSE: Standart Hatalar Toplamı, S.C.: Breusch-Godfrey LM otokorelasyon testi, J.-B.Nor.: Jarque-Bera normallik testi, Het.: ARCH testi, F.Res.: Ramsey Reset testi

Şekil 3'te yer alan CUSUM ve CUSUM-SQ grafiklerine göre, CUSUM-SQ'de küçük bir taşma olmasına rağmen çabuk bir şekilde geri kritik sınırlara döndüğü için modele ait uzun dönem katsayılarının istikrarlı olduğu anlaşılmaktadır. 
Şekil 3: ARDL CUSUM ve CUSUM-SQ grafikleri: toplam sağl1k harcamalarının GSYH
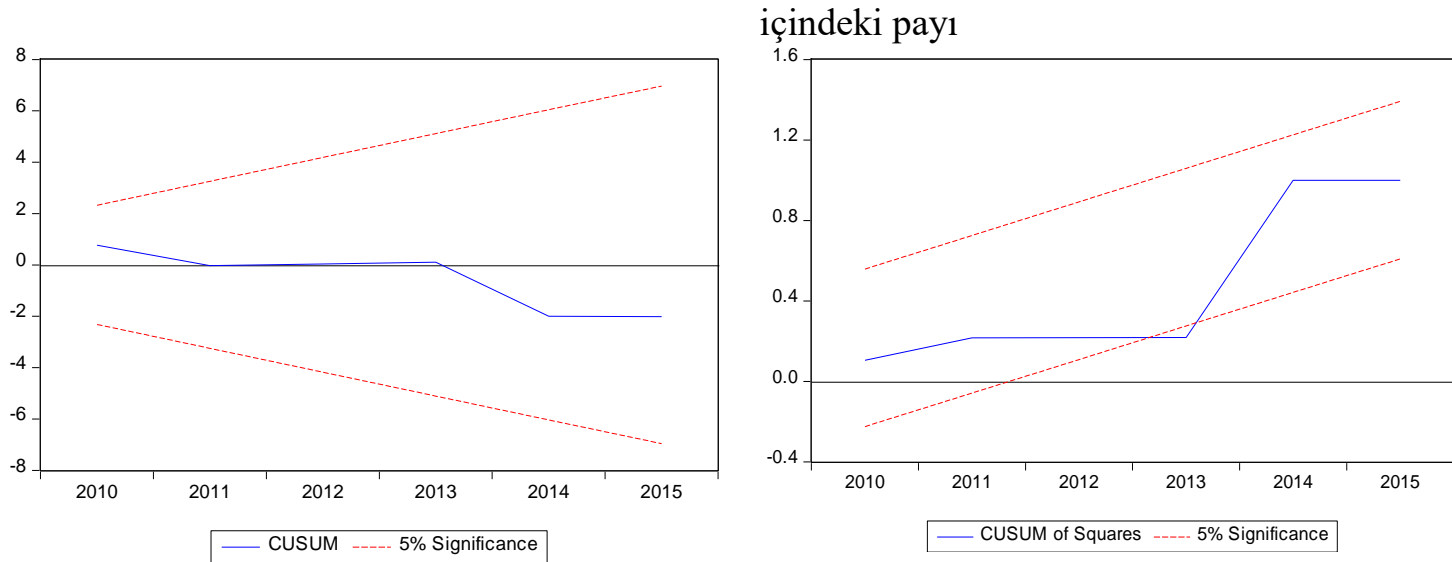

Tablo 6'daki bilgilerden ECM(-1)'in katsayısının beklenildiği gibi negatif ve istatistiksel olarak anlamlı olması hata düzeltme modelinin çalıştığını ve uzun dönem dengesinde kısa dönem şoklar nedeniyle meydana gelecek sapmaların \%23,8'inin bir sonraki dönemde düzeltileceğini göstermektedir.

Tablo 6'daki uzun dönem katsayılarından, enflasyon ve işsizlik oranının toplam sağlık harcamalarının GSYH içindeki payı arasında uzun dönemde ters yönlü olmakla birlikte istatistiksel olarak anlamlı bir ilişki olmadığı tespit edilmiştir. Diğer taraftan, reel GSYH ile toplam sağlı harcamalarının GSYH içindeki payı arasında ise \%90 güven düzeyinde anlamlı ve doğru yönlü bir ilişki bulunmaktadır.

Tablo 6'daki kısa dönem katsayılarından, 1994, 2001 ve 2009 ekonomik krizlerinin özel sağlık harcamalarının toplam sağlı harcamaları içindeki payı üzerinde ters yönlü etkide bulunmakla birlikte, 2001 ve 2009 ekonomik krizinin etkilerinin istatistiksel olarak anlamlı olduğu $(\mathrm{p}=0,000)$ tespit edilmiştir. Bu sonuçlardan, 2001 ve 2009 ekonomik krizlerinin, toplam sağlık harcamalarının GSYH içindeki payını anlamlı bir şekilde azalttıklarını söylemek mümkündür. Diğer taraftan önemli ölçüde olmasa bile 1994 ekonomik krizinin de azaltıcı etkisi ile birlikte değerlendirildiğinde, ekonomik krizlerin toplam sağlık harcamalarının GSYH içindeki payı üzerinde azaltıcı etkisinin bulunduğu ifade edilebilir. 2001 ekonomik krizinde, hem kamu sağlık harcamalarının hem de toplam sağlık harcamalarının anlamlı bir şekilde düşmesinde politika tercihin önemli bir etken olduğu düşünülmektedir. Diğer taraftan kamu sağlık harcamalarının önemli bir şekilde artarken özel sağlık harcamalarının önemli bir şekilde düştüğü 2009 ekonomik krizinde toplam sağlık harcamalarının anlamlı bir şekilde düşmesinde temel etkenin özel sağlık harcamalarındaki düşüş olduğu değerlendirilmektedir.

\subsubsection{Sağlık Bakanlığı Bütçesinin Genel Bütçe İçindeki Payı}

Bu aşamada, Sağlık Bakanlığı bütçesinin genel bütçe içindeki payı için genel bir ARDL modeli, maksimum gecikme uzunluğu 4 alınarak ve en uygun gecikme uzunluğu seçiminde Akaike bilgi kriteri kullanılarak OLS tekniği ile tahmin edilmesi sonucunda, ARDL [1, 0, 4, 4] modelinin en uygun model olduğuna karar verilmiştir. Daha sonra oluş̧urulan hata düzeltme modeli de yine en küçük kareler tekniği ile tahmin edilerek kısa dönem katsayıları elde edilmiştir. Tablo 7'de ARDL [1, 0, 4, 4] modelinin uzun ve kısa dönem katsayılarının tahmin sonuçları ve tanısal istatistikleri yer almaktadır. 
Çıraklı / Türkiye'de Makroekonomik Faktörler ile Sağlık Harcamaları ve Sağlık Bakanlığı Bütçesi Arasındaki

Tablo 3. ARDL modeli uzun ve kısa dönem tahmin sonuçları: Sağlık Bakanlığı bütçesi

\begin{tabular}{|c|c|c|c|c|c|c|c|}
\hline \multicolumn{8}{|c|}{ Tahmin Edilen ARDL Modeli: $[1,0,4,4]$} \\
\hline \multicolumn{4}{|c|}{$\begin{array}{l}\text { Uzun Dönem Modeli } \\
\text { Bağımlı Değişken: LSBBGBP }\end{array}$} & \multicolumn{4}{|c|}{$\begin{array}{c}\text { Kısa Dönem Modeli (ECM) } \\
\text { Bağımlı Değişken: } \Delta \text { LSBBGBP }\end{array}$} \\
\hline Değişkenler & Katsayı & $\mathbf{t}$ & $\mathbf{p}$ & Değişkenler & Katsayı & $\mathbf{t}$ & $\mathbf{p}$ \\
\hline LENF & 0,114 & 1,098 & 0,285 & $\triangle \mathrm{LENF}$ & 0,121 & 1,564 & 0,133 \\
\hline \multirow{4}{*}{ LRGSYH } & \multirow{4}{*}{3,805} & \multirow{4}{*}{$2,018 *$} & \multirow{4}{*}{0,057} & $\Delta$ LRGSYH & 2,723 & $2,978 * * *$ & 0,007 \\
\hline & & & & $\Delta$ LRGSYH(-1) & $-2,589$ & $-2,917 * * *$ & 0,008 \\
\hline & & & & $\Delta \mathrm{LRGSYH}(-2)$ & $-1,275$ & $-1,771$ & 0,091 \\
\hline & & & & $\Delta$ LRGSYH(-3) & $-1,321$ & $-1,746$ & 0,096 \\
\hline \multirow{4}{*}{ LISSIZ } & \multirow{4}{*}{2,277} & \multirow{4}{*}{$3,878 * * *$} & \multirow{4}{*}{0,001} & $\Delta$ LISSIZ & 0,627 & 2,054 & 0,053 \\
\hline & & & & $\Delta \operatorname{LISSIZ}(-1)$ & $-1,086$ & $-2,546 * *$ & 0,019 \\
\hline & & & & $\Delta \operatorname{LISSIZ(-2)}$ & $-0,504$ & $-1,390$ & 0,179 \\
\hline & & & & $\Delta \operatorname{LISSIZ}(-3)$ & $-0,632$ & $-2,081 * *$ & 0,049 \\
\hline D_1994 & 0,128 & 0,484 & 0,633 & $\Delta \mathrm{D} \_1994$ & 0,151 & 1,102 & 0,283 \\
\hline D_2001 & 0,190 & 0,597 & 0,557 & $\Delta \mathrm{D} \_2001$ & 0,296 & $2,113 * *$ & 0,047 \\
\hline D_2009 & 0,014 & 0,054 & 0,958 & $\Delta \mathrm{D} \_2009$ & 0,152 & 1,143 & 0,266 \\
\hline \multirow[t]{2}{*}{ @TREND } & $-0,154$ & $-1,969 *$ & 0,062 & Sabit & $-71,931$ & $-4,931 * * *$ & 0,000 \\
\hline & & & & $\operatorname{ECM}(-1)$ & -0.756 & $-4.926 * * *$ & 0.000 \\
\hline \multicolumn{8}{|c|}{$\begin{array}{c}\text { ECM }=\text { LSBBGBP }-(0,1141 * \text { LENF }+3,8053 * \text { LRGSYH +2,2772*LISSIZ + 0,1276*D_1994 + } \\
0,1899 * \text { D_2001 + 0,0142*D_2009 }-0,1537 * @ \text { TREND })\end{array}$} \\
\hline \multicolumn{8}{|c|}{$\begin{array}{c}\text { Tanisal Testler: SE: 0,145; SSE: 0,444; S.C.: 1,52, p: 0,240; J.-B.Nor.: 0,19, p: 0,908; Het.: 0,57, p: } \\
\text { 0,453; F.Res: 0,04, p: 0,831 }\end{array}$} \\
\hline
\end{tabular}

Tablo 7'de yer alan bilgilere göre, tahmin edilen ARDL [1, 0, 4, 4] modelinin tanısal istatistikler açısından (otokorelasyon, normal dağılıma uygunluk, değişen varyans ve model kurma hatası) herhangi bir problemi bulunmamaktadır. Yine Şekil 4'te yer alan CUSUM ve CUSUM-SQ grafiklerine göre, ARDL testi sonucunda elde edilen uzun dönem katsayılarının istikrarlı olduğu anlaşılmaktadır.

Şekil 4: ARDL CUSUM ve CUSUM-SQ grafikleri: Sağlık Bakanlığı bütçesi
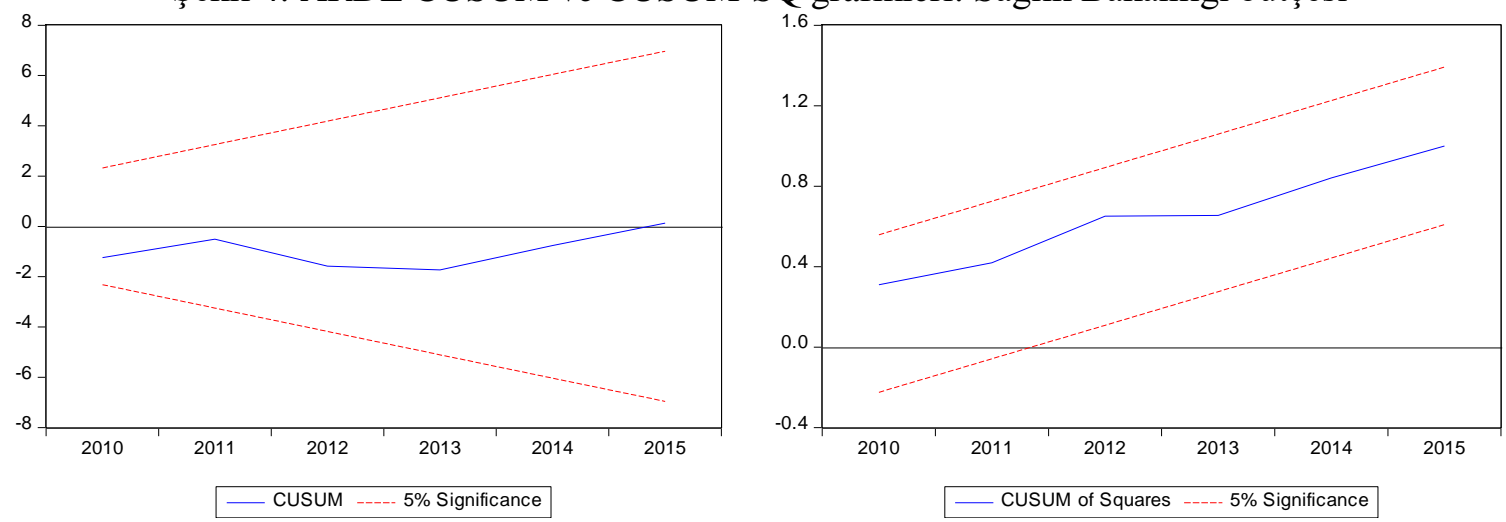

Tablo 7'de yer alan hata düzeltme modeli sonuçlarına göre, ECM (-1)'in katsayısının negatif $(-0,756)$ ve istatistiksel olarak anlamlı olduğu $(p=0,000)$ bulunmuştur. Buna göre, kısa dönemli şokların sistemin uzun dönem dengesinde neden olduğu sapmaların hızlı bir şekilde giderildiğini söylemek mümkündür.

Tablo 7'deki uzun dönem katsayılarına göre, enflasyon oranı ile Sağlık Bakanlığı bütçesinin genel bütçe içindeki payı arasında uzun dönemde anlamlı bir ilişki yoktur $(\mathrm{p}=0,285)$. Reel GSYH ile Sağlık Bakanlığı bütçesinin genel bütçe içindeki payı arasında ise, \%90 güven düzeyinde $(\mathrm{p}=0,057)$ doğru yönlü anlamlı bir ilişki bulunmaktadır. Yani Reel GSYH'deki artışın Sağlık Bakanlığı bütçesinin genel bütçe içindeki payını artırdığını söylemek mümkündür. 
Tablo 7'deki verilere göre, işsizlik ile Sağl1k Bakanlığ bütçesinin genel bütçe içindeki payı arasındaki ilişkinin doğru yönlü ve istatistiksel olarak anlamlı $(\mathrm{p}=0,001)$ olduğu tespit edilmiştir. Bu sonuçtan, uzun dönemde işsizlik oranındaki artışın Sağlık Bakanlığı bütçesinin genel bütçe içindeki payını artırıcı etki yaptığını söylemek mümkündür.

Ekonomik krizlerin Sağlık Bakanlığı bütçesinin genel bütçe içindeki payı üzerindeki etkileri incelendiğinde, Tablo 7'deki kısa dönem tahmin sonuçlarına göre, 1994, 2001 ve 2009 ekonomik krizlerinin Sağlık Bakanlığı bütçesinin genel bütçe içindeki payını artırıcı etki yaptıkları ancak bunlardan sadece 2001 ekonomik krizinin etkisinin anlamlı olduğu $(p=0,047)$ tespit edilmiştir. Genel bir değerlendirmeyle, Türkiye'de ekonomik kriz dönemlerinde politik tercihin krizin olası olumsuz etkilerinden toplumu korumak için bütçeyi artırmak şeklinde gerçekleştiğini söylemek mümkündür.

\section{Sonuç ve Öneriler}

Bu çalışma, makroekonomik faktörler ile sağlık harcamaları ve Sağlık Bakanlığı bütçesi arasındaki ilişkilerin ve makroekonomik faktörlerdeki değişimin sağlık harcamalarını ve Sağlık Bakanlığı bütçesini etkileyip etkilemediğinin ortaya koymak amacıyla gerçekleştirilmiş̧tir. Bu kapsamda, 1974-2015 yılları arası reel GSYH, işsizlik, enflasyon, sağlık harcamaları ve Sağlık Bakanlığı bütçesi verileri ARDL (Autoregressive Distributed Lag) sınır testi yaklaşımı kullanılarak incelenmiştir.

Çalışma sonucunda, uzun dönemli ilişkiler kapsamında, Reel GSYH'deki artışın kamu sağlık harcamalarının toplam sağlık harcamaları içindeki payını artırıcı şekilde anlamlı bir etkisinin $(p<0.05)$ olduğu, enflasyon ve işsizliğin ise önemli etkilerinin olmadığı sonucuna ulaşılmıştır. Özel sağlık harcamalarının toplam sağlık harcamaları içindeki payı açısından ise, uzun dönemde hem Reel GSYH'deki hem de enflasyondaki artışın özel sağlık harcamalarının toplam sağlık harcamaları içindeki payının anlamlı bir şekilde azaltıcı etkilerinin olduğu, işsizliğin ise önemli bir etkisinin olmadığı bulunmuştur. Toplam sağlık harcamalarının GSYH içindeki payı açısından ise, enflasyon ve işsizliğin uzun dönemde önemli etkilerinin olmadığı, Reel GSYH'nin ise \%90 güven düzeyinde artırıcı etkisinin olduğu sonucuna ulaşılmıştır.

Uzun dönemde reel gelir arttığında kamu sağlık harcamalarının toplam sağlık harcamaları içindeki payının artması beklenebilir bir durumdur. Çünkü gelir artışı kamunun sağlığa yeterli kaynak ayırabilmesinin önemli bir unsurudur. Enflasyonun uzun dönemde bireylerin özel sağlık harcamalarını önemli ölçüde azaltmasında, Türkiye'nin önemli ölçüde tıbbi cihaz ve malzeme ithalatçısı konumunda olmasının ve neticesinde enflasyon nedeniyle artan tıbbi mal ve hizmetlerin fiyatlarının bireylerin özel sağlık harcaması yapma imkânını önemli ölçüde kısıtlamasının önemli bir etken olduğu düşünülmektedir. Bu nedenle Türkiye'nin tıbbi cihaz ve malzeme açısından ithalatçı konumdan çıkarak üretici konumuna gelecek ar-ge yatırımlarını yapması büyük önem taşımaktadır.

Uzun dönem ilişkiler kapsamında Sağlık Bakanlığı bütçesiyle ilgili sonuçlar değerlendirildiğinde, uzun dönemde işsizlik oranındaki artışın Sağlık Bakanlığı bütçesinin genel bütçe içindeki payını anlamlı şekilde artırıcı etki yaptığ sonucuna ulaşılmıştır. Bu sonucun, temel olarak politik tercihin önemli bir yansıması olduğu ve Türkiye'nin bu kapsamda genişletici bir politika benimsediği söylenebilir. Çünkü uzun dönem kapsamında, işsizliğin sağlığa olumsuz etkilerinden koruyacak programlara ayrılacak kaynaklar açısından bütçenin artırılması önemlidir.

Ekonomik krizlerin Türkiye'de sağlık harcamaları ve Sağl1k Bakanlığı bütçesi üzerindeki etkileri kapsamında bu çalışmada, ilk olarak 1994 ekonomik krizinin kamu sağlık harcamaları ve Sağlık Bakanlığı bütçesi için pozitif, özel sağlık harcamaları ve toplam sağlık harcamaları için negatif yönlü olmakla birlikte sağlık harcamaları ve Sağlık Bakanlığı bütçesine önemli etkisinin olmadığ 1 ( $>>0.05)$ bulunmuştur. 2001 ekonomik krizinde ise, özel sağlık harcamaları üzerinde negatif yönlü olmakla birlikte önemli bir etki görülmezken, kamu sağlık 
harcamaları ve toplam sağlık harcamalarının önemli şekilde $(\mathrm{p}<0,05)$ azaldığı, Sağlık Bakanlığ bütçesinin ise önemli bir şekilde $(p<0.05)$ arttı̆g 1 sonucuna ulaşılmıştır. 2009 ekonomik krizinin etkisi ise, kama sağlık harcamaları için anlamlı bir şekilde $(\mathrm{p}<0,05)$ pozitifken, özel sağlık harcamaları ve toplam sağlık harcamaları için önemli şekilde $(p<0,05)$ negatif yönde gelişmiştir. Sağlık Bakanlığı bütçesi için 2009 ekonomik krizinin katsayısı pozitif yönlü olmakla birlikte bu etki anlamlı bulunmamıştır ( $\mathrm{p}>0,05)$.

Genel olarak değerlendirmek gerekirse, bu çalışmada elde edilen uzun dönem ilişkilerden, Türkiye'de gelir artışının kamuda sağlığa ayrılan payı artırdığı ve aynı zamanda bu sonucun politik bir tercihi yansıtması nedeniyle politikacıların da gelirle doğru orantılı şekilde sağlığa kaynak ayırmayı tercih ettiği ifade edilebilir. Benze şekilde, işsizliğin negatif yönlü olmakla birlikte uzun dönemde sağlık harcamalarını önemli şekilde olumsuz etkilememesinin, Türkiye'nin sosyal güvenlik sisteminin güçlü bir yapıya sahip olduğunu gösterdiği düşünülmektedir. Diğer taraftan, enflasyon artışının özel sağlık harcamalarını azaltıcı etkisi toplumun sağlık hizmeti ihtiyaçlarının karşılanamaması riskini beraberinde getireceği için Türkiye'nin tıbbi cihaz ve malzeme açısından ithalatçı konumdan çıkarak üretici konumuna geçmesi için ar-ge yatırımlarına önem vermesi büyük önem taşımaktadır.

Türkiye'de ekonomik krizlerin ise genel olarak özel sağlık harcamaları üzerinde azaltıcı etki yaptıkları, kamu sağlık harcamaları ve Sağlık Bakanlığı bütçesi üzerindeki etkilerin krizin şiddetiyle ve politik tercihle yakından ilgili olduğu ifade edilebilir. Bu kapsamda Türkiye'nin sadece 2001 ekonomik krizinde kamu sağlık harcamalarının önemli ölçüde düşmesi ve Sağlık Bakanlığı bütçesinin ise genel olarak artırılması Türkiye'de özellikle son on beş yılda genel olarak geniş̧letici politika tercihinde bulunulduğunu göstermektedir. Ayrıca son on yılda sosyal güvence sisteminde, Genel Sağlık Sigortası ile tüm nüfusun kapsama alınması da Türkiye'de sağlıkta genişletici politika tercihinin ön sırada olduğunu göstermektedir. Bu açıdan, genişletici polika tercihinin krizlerin olası olumsuz sağlık etkilerinin önlenmesinde Türkiye için olumlu olduğu ifade edilebilir.

\section{Kaynakça}

Aggleton, P. (1990). Health. London: L \& L Composition Ltd.

Bahmani-Oskooee, M. \& Ng, R. C. W. (2002). Long-Run Demand for Money in Hong Kong: An Application of the ARDL Model. International Journal of Business and Economics, 1(2), 147-155.

Blum, H. L. (1974). Planning for Health: Development and Application of Social Change Theory. New York: Human Sciences Press.

Brunner, E. ve Marmot, M. G. (2006). Social Organization, Stress and Health. In Marmot, M. G. \& Wilkinson, R. G. (Ed.). Social Determinants of Health. Oxford: Oxford University Press.

Bulutay, T. (1995). Employment, Unemployment and Wages in Turkey. ILO, Ankara: Devlet İstatistik Enstitüsü.

BUMKO. (2016). Istatistikler: Bütçe Büyüklükleri ve Bütçe Gerçekleşmeleri. http://www.bumko.gov.tr/TR,157/butce-buyuklukleri-ve-butce-gerceklesmeleri.html (Erişim: 02 Ekim 2016).

Catalano, R. (2009). Health, Medical Care, and Economic Crisis. The New England Journal of Medicine, 360(8), 749-751.

Christian, P. (2009). Impact of the Economic Crisis and Increase in Food Prices on Child Mortality: Exploring Nutritional Pathways. The Journal of Nutrition, 140, 177-181. 
Çiftci, F. (2009). Küreselleşme Sürecinde Gelişmekte Olan Ülkelere Yönelik Sermaye Akımlarının Ekonomik Büyüme Üzerindeki Etkileri: Türkiye Örneği. Yayınlanmamış Yüksek Lisans Tezi, Muğla Üniversitesi, Sosyal Bilimler Enstitüsü, Muğla.

Çiftci, F. ve Yıldız, R. (2015). Doğrudan Yabancı Yatırımların Ekonomik Belirleyicileri: Türkiye Ekonomisi Üzerine Bir Zaman Serisi Analizi. Business and Economics Research Journal, 6(4), 71-95.

Dahlgren, G. ve Whitehead, M. (1991). Policies and Strategies to Promote Social Equity in Health. Institute for Future Studies.

Darby, J. ve Melitz, J. (2008). Social Spending and Automatic Stabilisers in the OECD. Economic Policy, 23, 715-716.

Del Grenado, J. A., Gupta, S.ve Hajdenberg, A. (2010). Is Social Spending Procyclical? IMF Working Paper, WP/10/234, IMF.

Evans, R. G. ve Stoddart, G. L. (1990). Producing Health, Consuming Health Care. Social Science \& Medicine, 31(12), 1347 - 1363.

HPC (Healthy Public Policy). (2011). Social Environments and Health. Concept Paper. Edmonton: Alberta Health Services.

Kalkınma Bakanlığı. (2014). Onuncu Kalkınma Planı (2014-2018) Tıbbi Cihaz ve Tıbbi Malzeme Çalışma Grubu Raporu. Ankara.

Kalkınma Bakanlı̆̆ı. (2015). Ekonomik ve Sosyal Göstergeler (1950-2015). T.C. Kalkınma Bakanlığı, Ankara.

Kavuncubaşı, Ş. ve Yıldırım, S. (2010). Hastane ve Sağlık Kurumları Yönetimi. Ankara: Siyasal Kitapevi.

Keegan, C., Thomas, S., Normand, C. ve Portela, C. (2013). Measuring recession severity and its impact on healthcare Expenditure. Int. J. Health Care Finance Econ., 13(2), 139-155, DOI 10.1007/s10754-012-9121-2

Kontorovich, V. (2001). The Russian Health Crisis and the Economy. Communist and PostCommunist Studies, 34, 221-240.

Lalonde, M. (1974). A New Perspective on the Health of Canadians. A Working Document. Ottowa: Government of Canada.

OECD. (2016e). OECD Statistics: Health Expenditure and Financing. http://stats.oecd.org/ (Erişim: 05 Ağustos 2016).

Özer, Ö., Yıldırım, H. H. ve Yıldırım, T. (2015). Sağllk Sistemlerinde Finansal Sürdürülebilirlik: Kuram ve Uygulama. Ankara: ABSAM Yayınlar1.

Pesaran, M. H., Shin, Y. \& Smith, R. J. (2001). Bounds Testing Approaches to the Analysis of Level Relationships. Journal of Applied Econometrics, 16(3), 289-326.

Ruckert, A. \& Labonte, R. (2012). The Global Financial Crisis and Health Equity: Toward a Conceptual Framework. Critical Public Health, 22(3), 267-279.

İTO (İstanbul Ticaret Odas1) ve Sargutan, A. E. (2009). Trbbi Cihaz ve Malzeme İthalatı, Yarattı̆̆ Kayıplar ve Çözüm Önerileri. İstanbul: Rema Matbaacılık.

Somunoğlu, S. (2012). Sağlık-Sağlık Sistemleri ve Türk Sağl1k Sistemi. İçinde: Tatar, M. (Ed.), Sağllk Kurumları Yönetimi-I (2-26). Eskişehir: Anadolu Üniversitesi Açıköğretim Fakültesi Yayını No: 2631. 
Şahin, B. (1996). Sağllk Statüsünün Ölçülmesi: Bypass Ameliyatı Olan Hastaların Algılanan Sağllk Statüleri Üzerine Bir Araştırma. Yüksek Lisans Tezi, Hacettepe Üniversitesi, Sağlık Bilimleri Enstitüsü, Sağlık Kurumları Yönetimi, Ankara.

Tangcharoensathien, V., Harnvoravongchai, P., Pitayarangsarit, S. \& Kasemsup, V. (2000). Health Impacts of Rapid Economic Changes in Thiland. Social Science \& Medicine, 51, 789907.

Thomas, S., Keegan, C., Barry, S., Layte, R., Jowett, M. ve Normand, C. (2013). A Framework for Assessing Health System Resilience in an Economic Crisis: Ireland as a Test Case. BMC Health Services Research, 13:450.

Tunçsiper, B. \& Biçen, Ö. F. (2013), “Avrupa Borç Krizinin Türkiye'nin İhracatı Üzerindeki Etkileri”, in S. Sarı, A. H. Gencer \& İ. Sözen (Eds.). Proceedings of Inernational Conference on Eurasian Economies, 17-18 September, St. Petersburg, Russia, 486-495.

TÜIKK. (2016). İsgü̈cü Istatistikleri. http://www.tuik.gov.tr/PreTablo.do?alt_id=1007 (Erişim: 8 Ağustos 2016).

Williams, M. N., Grajales, C. A. G. and Kurkiewicz, D. (2013). Assumptions of Multiple Regression: Correcting Two Misconceptions. Practical Assessment, Research \& Evaluation, 18(11), 1-14.

WHO. (1948). Constitution. Geneva: WHO.

World Bank. (2016a). World Development Indicators. [http://databank.worldbank.org/data/reports.aspx?source=2\&country=TUR\#] (Erişim: 4 Ağustos 2016).

World Bank. (2016b). World Development Indicators. [http://databank.worldbank.org/data/reports.aspx?source=2\&country=TUR\#] (Erişim: 8 Eylül 2016).

Yıldırım, H. H. (2015). Sağlık ve Siyaset Yazıları, 1. Baskı. Ankara: ABSAM Yayınları. 